\title{
One of Us: Multilevel Models Examining the Impact of Descriptive Representation on Civic Engagement
}

\section{Citation}

Norris, Pippa, and Mona Lena Krook. 2009. One of Us: Multilevel Models Examining the Impact of Descriptive Representation on Civic Engagement. HKS Faculty Research Working Paper Series RWP09-030, John F. Kennedy School of Government, Harvard University.

\section{Published Version}

http://web.hks.harvard.edu/publications/workingpapers/citation. aspx?Publd=6797

\section{Permanent link}

http://nrs.harvard.edu/urn-3:HUL.InstRepos:4448881

\section{Terms of Use}

This article was downloaded from Harvard University's DASH repository, and is made available under the terms and conditions applicable to Other Posted Material, as set forth at http:// nrs.harvard.edu/urn-3:HUL.InstRepos:dash.current.terms-of-use\#LAA

\section{Share Your Story}

The Harvard community has made this article openly available.

Please share how this access benefits you. Submit a story.

\section{Accessibility}




\author{
Faculty Research Working Papers Series
}

\title{
One of Us: Multilevel Models Examining the Impact of Descriptive Representation on Civic Engagement
}

\author{
Pippa Norris \\ John F. Kennedy School of Government - Harvard University
}

Mona Lena Krook

Washington University in St. Louis

September 2009

RWP09-030

The views expressed in the HKS Faculty Research Working Paper Series are those of the author(s) and do not necessarily reflect those of the John F. Kennedy School of Government or of Harvard University. Faculty Research Working Papers have not undergone formal review and approval. Such papers are included in this series to elicit feedback and to encourage debate on important public policy challenges. Copyright belongs to the author(s). Papers may be downloaded for personal use only. 


\section{One of Us:}

\section{Multilevel models examining the impact of descriptive representation on civic engagement}

\section{Pippa Norris and Mona Lena Krook}

\begin{tabular}{ll}
\hline Pippa Norris & Mona Lena Krook \\
McGuire Lecturer in Comparative Politics & Department of Political Science \\
John F. Kennedy School of Government & Washington University in St. Louis \\
Harvard University & 281 Seigle Hall, One Brookings Drive \\
Cambridge, MA 02138 & St. Louis, Missouri 63130 \\
Pippa Norris@Harvard.edu & mlkrook@wustl.edu \\
www.pippanorris.com & $\underline{\text { http://krook.wustl.edu/ }}$ \\
\hline
\end{tabular}

Synopsis: This paper examines the impact of descriptive representation in comparative perspective. The goals are to establish (1) whether descriptive representation mobilizes attitudinal and behavioral indicators of civic engagement; (2) whether the strength of any such relationship differs for women and young people; and (3) whether this relationship is evident cross-nationally. The first section provides an overview of existing research on descriptive representation and the civic engagement of women and young people. The second section presents the research design. The third reports and discusses the findings of the multilevel models and what these suggest about relationships between descriptive representation in national parliaments and patterns in civic engagement among citizens. The paper concludes with a summary of the major findings and reflects upon their implications for understanding and altering long-standing inequalities in civic engagement.

Keywords: Political participation, descriptive representation, gender and young people.

Paper for presentation in panel 34-6 'Beyond the Ballot Box: Institutions, Participation and Representation' at the Annual Meeting of the American Political Science Association, Toronto, 10.15am Thursday September $3^{\text {rd }} 2008$. 
Political representation takes many forms. Hanna Pitkin (1967) offers a widely-used conceptualization distinguishing four main types: descriptive, where the composition of elected bodies reflects the diverse characteristics of the electorate; authorized, where a person is legally empowered to act for another; symbolic, where a leader stands for a national idea; and substantive, where a representative seeks to advance a group's policy preferences, needs, or interests. Subsequent research explores both the nature of single categories of representation, as well as the potential interrelations between them. Descriptive representation has received perhaps the most extensive treatment in theoretical and comparative research, with scholars presenting various reasons concerning the importance of more inclusive and diverse legislatures (Pitkin 1967; Phillips 1995; Williams 1998; Mansbridge 1999, 2003; Young 2000; Lovenduski 2005).

For example, they suggest that when parliaments mirror the population from which they are drawn, this may be important for the democratic legitimacy of elected bodies, especially by providing a voice for historically disadvantaged groups (Banducci, Donovan, and Karp 2004; Schwindt-Bayer and Mishler 2005). At the most extreme, parliaments which exclude any major social sector from standing for elected office fail to meet universal standards of human rights. Descriptive representation may also be crucial for ensuring substantive representation. Some studies show that the identities of legislators affect the types of measures prioritized, proposed, and passed on behalf of different groups (Canon 1999; Swers 2002; Tate 2003; Childs 2004), although importantly, other scholars dispute these claims (cf. Cameron, Epstein, and O'Halloran 1995; Lovenduski and Norris 2003; Tate 2003; Wängnerud 2009).

The symbolic and substantive effects of descriptive representation continue to be debated. However, there is a third potential effect - the impact of descriptive representation on patterns of civic engagement - which has been the subject of less study. Yet, two well-established patterns suggest that this may be a promising avenue of investigation. On the one hand, despite the fact that there are often few official restrictions on the qualifications required to run for political office, most parliamentarians around the world come from socially, economically, and politically privileged backgrounds. Among other characteristics, they are often overwhelmingly male and middle-aged (Norris 1997; Best and Cotta 2000; Borchert and Zeiss 2003). On the other hand, for many years research on political participation has identified persistent social inequalities in civic involvement. An enduring them of this literature from the very earliest studies is that women are usually less politically active than men, while the younger generation are commonly less engaged than their parents and grandparents (Tingsten 1937; Almond and Verba 1963; Rokkan 1970; Verba, Nie, and Kim 1978). Although typically analyzed separately, parallel disparities in the composition of legislative elites and in mass political participation suggest that these may, in fact, be linked. Seeking to bridge these two areas of research, this paper draws on substantial cross-national variations within and across groups to ask: does descriptive representation mobilize civic engagement?

A links between these factors is commonly assumed. During the 2008 U.S. presidential election, for example, popular commentary frequently predicted that the social cues presented by the candidacy of Barack Obama would mobilize activism among the younger generation, particularly among AfricanAmericans, expectations that were partially borne out by state turnout figures and exit polls (Gans 2009). Yet the available systematic empirical research into this question is largely inconclusive, segmented into separate bodies of work examining women and youth, and often focused on the United States. Research on gender primarily seeks to understand the effects of viable female candidates and elected officials on mass political attitudes and the propensity of women and men to engage in a variety of political activities. With few exceptions (cf. Karp and Banducci 2008; Wolbrecht and Campbell 2007), little attention has been paid to comparisons across more than one country. Studies of youth devote most attention to the long-term effects of socialization on the propensity of young people to engage in 
politics during their lifetime. A major concern is the relatively low levels of turnout witnessed among the younger generation and their future implications (Jennings and Stoker 2004; Franklin 2004; Franklin, Lyons, and Marsh 2004). In contrast, research has not examined systematic connections between the descriptive representation of young people in parliament and their propensity for political engagement.

Building on these literatures, but also seeking to overcome these important gaps, this paper examines the impact of descriptive representation in comparative perspective. The goals are to establish (1) whether descriptive representation mobilizes attitudinal and behavioral indicators of civic engagement; (2) whether the strength of any such relationship differs for women and young people; and (3) whether this relationship is evident cross-nationally. The first section begins with an overview of existing research on the descriptive representation and civic engagement of women and youth. On this basis, it proposes a series of theoretical expectations with regard to how the descriptive representation of these groups might alter patterns of political engagement.

A key intuition is that the perception from visual cues that leaders look more like "one of us" may mobilize members of these groups who feel that elected bodies are thereby more responsive to their interests and concerns. In other words, social stereotypes about candidates and elected officials can be understood to function as cognitive shortcuts, which are especially useful for evaluative decision-making in the absence of other detailed information. Alternatively, following the same logic, lack of visible representation may depress political interest and activism by these social sectors. The second section presents the research design, outlining the data and methods used. The third section reports and discusses the findings of the multilevel models and what these suggest about relationships between descriptive representation in national parliaments and patterns in civic engagement among citizens. The paper concludes with a summary of the major findings and reflects upon their implications for understanding and altering long-standing inequalities in civic engagement.

\section{Descriptive Representation and Civic Engagement}

A wealth of scholarship has long observed relatively low levels of civic engagement among women, the working class and less educated, racial and ethnic minorities, and young people. Social psychological research attributes these patterns to the fact that members of these groups have fewer political resources - like education, income, and levels of self-confidence - as compared to members of dominant groups (Verba, Nie, and Kim 1978). Others suggest, however, that the external political environment may provide important "cues" regarding standards of appropriate behavior: a government that consists largely of older white men may create psychological barriers that lead to reduced levels of political interest and engagement among the sectors that do not fit this profile (Atkeson 2003; Bobo and Gilliam 1990; Hansen 1997). The first perspective assumes that the reasons for group-based differentials are rooted in micro-level socioeconomic disparities. The second, however, considers the possibility that the composition of the macro-level political elite has symbolic importance for group members, who may make their decision to participate based on the presence or absence of people who appear to be "like them" in positions of political power.

Theoretical and empirical literature on descriptive representation of marginalized groups suggests several pathways by which this dynamic might occur. One possibility is that this process may influence perceptions as to whether or not members of these groups are capable of governing, or 'fit' to rule (Mansbridge 1999). A second is that increased group presence may signal greater openness of the political system, encouraging group participation and potentially leading elected group members to serve as political role models for others in the group (Burns, Schlozman, and Verba 2001; Phillips 1995). $A$ third relates to questions of policy responsiveness: when their members are present, groups may feel 
that they have greater voice and input in policy-making processes (Atkeson and Carrillo 2007; Williams 1998; Young 2000).

Building upon these insights, the theoretical argument emphasized in this study suggests that descriptive representation among visible political minorities can be understood to function as a cognitive shortcut which facilitates judgments by electors. Even if voters know relatively little about candidates and elected officials, the social stereotypes derived from the visual cues of sex and age may provide short-cuts that can guide judgments at the ballot box, as well as shape images and evaluative attitudes about the responsiveness of the legislature and the broader political system. Because identities like sex and age are salient means of categorizing others, according to research on social perception (Kunda 1999), the general absence of women and the young from political office may cause members of these, as well as dominant groups, to assume that the former are not qualified to govern. Stereotypes such as these may lead to fewer aspirations among group members to hold elected office or to engage in political activity more generally. While these dynamics take the form of a self-fulfilling prophecy (Jussim and Fleming 1996), scholars observe that they may nonetheless be interrupted. Processing inconsistencies, individuals may alter their views on these stereotypes through incremental updating, conversion, reclassification, and role model effects (Hilton and von Hippel 1996). This work thus suggests that behaviors inconsistent with stereotypical expectations may lead to broad changes in the perceptions of dominant and marginalized groups.

All of these pathways suggest that group presence will lead members to feel more closely connected to the political system, generating increased levels of civic engagement. Despite these shared assumptions, the evidence thus far on the impact of descriptive representation is mixed, with important gaps in research on these questions within and across identity groups. Moreover, even where there is a consensus emerging about the main findings in the research literature based on the United States, it remains difficult to generalize about the impact of descriptive representation on civic engagement in other political systems. The United States is a plural society with a strong sense of identity politics where congressional elections in single member districts are based upon entrepreneurial candidates, localized and personalized campaigns, and exceptionally weak local party organizations (Jacobson 2004). In global perspective, the United States Congress also contains relatively few women and younger representatives (see Table A2).

It is plausible that many institutional factors will shape the impact of descriptive representation in any country; for example, the role of cognitive shortcuts derived from the social characteristics of candidates can be expected to weaken for citizens living in countries where alternative information cues are widely available, including in national legislative elections with political parties characterized by strong parliamentary discipline, centralized national leadership, and programmatic platforms; in electoral systems with multi member districts and party list proportional representation rather than single member districts; and in media systems which emphasize national over local politics. Carey and Shugart (1995) emphasize that single member districts are associated more strongly personalistic voting (including on the basis of social cues about candidates) whereas multi-member districts generate incentives for stronger party voting. Whether societies are relatively homogeneous or heterogeneous could also be expected to shape the political salience of social cleavages. In states transitioning towards democracy, as well, the identity politics of descriptive representation may prove more important for initial elections, when multiple parties have not yet developed a clear ideological orientation, coherent program, or legislative record, than for subsequent contests. For all these reasons, it is important to establish whether any generalizations about the impact of descriptive representation remain robust in comparative perspective. 


\section{Women}

A series of seminal studies of political participation have long reported that women were less politically engaged than men in many established democracies. The earliest studies of electoral behavior in Western Europe and North America, conducted during the 1920s and 1930s shortly after the female franchise was granted in many countries, commonly observed that men were more likely to vote than women (Gosnell 1930; Merriam 1924; Tingsten 1937). Two decades later, a UNESCO report found that sex was one of the standard factors predicting levels of electoral turnout and of party membership in Western Europe (Duverger 1955). During the 1960s and early 1970s, a survey of all conventional forms of political participation - voting turnout, party membership, contact activity, and community organizing - in seven nations concluded: "[i]n all societies for which we have data, sex is related to political activity; men are more active than women" (Verba, Nie, and Kim 1978). The activism gap persisted, even after controlling for differences between women and men in their education, trade union membership, and psychological involvement in politics.

During the same era, another study found that women were also less engaged in more unconventional forms of participation, like strikes and demonstrations (Barnes and Kaase 1979). These gender gaps remained in evidence in the 1980s and 1990s in many countries, even in the United States and Western Europe where women had been enfranchised with full citizenship rights for decades (InterParliamentary Union 1997; Inter-Parliamentary Union 2000). Despite major changes in lifestyles, the workforce, and the home and family, women continue to be less engaged than men in many political activities: although the gap is modest, men continue to predominate in both traditional forms of activism and protest politics. Nonetheless, the gender gaps are usually greatest in developing countries, and there is some evidence that gender gaps on certain indicators have been closed among younger generations (Inglehart and Norris 2003).

The enduring nature of these gaps, despite significant social, economic, and political change, has led a growing number of scholars to consider whether the increased presence of female candidates and elected officials may help shrink these differences in civic engagement. The evidence thus far is mixed, but with few exceptions, most of this research focuses on individual countries, especially the U.S., over a limited range of years. As a consequence, divergent findings may be the result of different contexts, measures, and sources of data. This is true even of literature on the U.S. case, which usually analyzes trends in responses in the National Election Study, but examines these in an assortment of years from the 1980s through the 2000s and in relation to descriptive representation in a variety of political offices.

One set of studies finds that the presence of female candidates and office-holders has positive effects on women's political interest, knowledge, participation, and sense of political efficacy (Burns, Schlozman, and Verba 2001; High-Pippert and Comer 1998; Sapiro and Conover 1997; for similar results in the U.K., see Norris, Lovenduski, and Campbell 2006). Others find, however, that an increase in some attitudes and behavior is experienced equally by women and men (Dolan 2006). A third group qualifies these patterns, noting that positive effects appear when women are viable candidates, leading to high visibility in news coverage (Atkeson 2003; Campbell and Wolbrecht 2006); in elections when gender issues are strongly politicized (Hansen 1997; Koch 1997); and via the mediating factor of political party, in the sense that voters respond primarily to changes in recruitment patterns in their own parties (Reingold and Harrell forthcoming; for similar findings on party ideology in the Netherlands, see Koning 2009). A final set of studies presents mixed results, depending on the activities and offices under investigation (Atkeson and Carrillo 2007; Lawless 2004).

Until recently, little research explored the links between descriptive representation and civic engagement in cross-national perspective. Nevertheless a wave of new comparative studies provides some insights into broader patterns, although this work is also limited in important ways, with cases 
driven by the availability of cross-national data. For the most part, these analyses are restricted to postindustrial societies and established democracies in Western Europe, North America, Australia, and New Zealand, although some studies do include a handful of non-Western cases, like South Korea, Japan, and Brazil. The source of survey data is also more diverse than that used to study the U.S. case, with scholars utilizing responses from the European Values Survey, the European Social Survey, and the Civic Education Study to analyze 23, 22, and 20 nations (Wolbrecht and Campbell 2007); questions from the Comparative Study of Electoral Systems project to explore trends in 35 countries (Karp and Banducci 2008); and data from the World Values Survey to examine 25 and 31 cases, respectively (Alexander 2009; Schwindt-Bayer and Mishler 2005).

Taken together, these studies reach a similarly diverse set of conclusions. Investigating the relationship between descriptive representation and civic engagement, one scholar finds that women's presence in parliaments is associated with significant, positive changes in social perceptions of women's ability to rule (Alexander 2009). Addressing potential role model effects, another study finds that where there are more women in parliament, adolescent girls are more likely to discuss politics with friends and to intend to participate in politics as adults. Adult women are also more likely to discuss and participate in politics, but the impact is far greater among the young (Wolbrecht and Campbell 2007). In contrast, other work observes few differences in the effects on women versus men, finding that higher proportions of women in parliament lead to greater levels of confidence in the legislature (Schwindt-Bayer and Mishler 2005) and levels of satisfaction with the political process (Karp and Banducci 2008), but not conditional on the sex of the respondent. Further, one analysis concludes that the descriptive representation of women appears to have no effect on shrinking gender gaps in political mobilization (Karp and Banducci 2008). These varied results suggest that more analytical leverage might be gained by undertaking a comparative study, which examines a broader and more diverse range of countries over a greater length of time, using a shared template of questions and responses.

Youth

The literature on political participation has also identified age to be one of the most fundamental predictors of rates of political engagement, including electoral turnout, patterns of party membership, involvement in voluntary organizations, and participation in group activity. One particularly thorough study of trends in the U.S. emphasizes that a long-term secular trend generated overall turnout decline, with the post-New Deal generation being consistently less likely to vote than members of the previous two generations. The authors suggest that this phenomenon was not the product of lifecycle or again, but rather represented an enduring shift among the generation who first came to political consciousness during the turbulent politics of the 1960s. As such, the long-term slide in American turnout, they conclude, is due to the process of generational replacement, not a fall in the propensity of the older generations to turn out to vote (Miller and Shanks 1996).

Other scholars attribute this decline, however, to an erosion of civic mobilization in the U.S. since the 1960s and 1970s, as indicated by a reduced likelihood overall of attending political rallies or speeches, working for a political party, and writing to Congress, as well as being active within informal associations in the local community (Putnam 2000). Cross-national evidence indicates that these patterns are not confined to the U.S. For example, a study of reported voting in 22 countries based on a survey undertaken by the International Social Survey Programme finds that, in general, just $55 \%$ of voters under the age of 25 voted, as compared with $88 \%$ of the late middle-aged, by far the largest participation gap found for any demographic or social group (Norris 2003). These disparities are likely to have enduring effects, according to generational theories of political socialization which suggest that behavior in elections when citizens first reach voting age may generate habits of electoral participation that last a lifetime (Franklin 2004; Plutzer 2002). 
To the degree that there is research on young members of parliament, this tends to focus on their experiences in office (see for example Burness 2000), not their effects on young voters. However, there is extensive research on trends and determinants of the political participation of young people, which can be used to speculate how increased descriptive representation might affect levels of civic engagement in those under the age of 40 . On the one hand, studies suggest that the cohort of voters born after 1965 or 1970 tend to participate at much lower levels than their parents and grandparents because, different from earlier generations, they have not become adults during years of substantial political struggle, but rather at a moment where trust and confidence in political institutions hovers at low levels, voter turnout has declined, and widespread social movements have disappeared (Jennings and Stoker 2004). For these reasons, a study hypothesizes that the symbolic impact of black officeholding is likely to be strongest among older blacks, who came of political age in a segregated society and therefore are more likely to believe that black office-holding is an important step forward, whereas younger blacks socialized in a period when black office-holding is more common may be less so inclined (Gilliam 1996).

On the other hand, notable political events may catalyze pre-adult socialization, if a set of issues is particularly prominent (Sears and Valentino 1997). In addition, membership in politically salient youth organizations - that is, service organizations, student council, drama clubs, musical groups, and religious organizations - is associated with higher levels of adult political participation (McFarland and Thomas 2006). This may overcome the lack of political information and interest reported by many young people, which when introduced as a statistical control, eliminates the age gap in voter turnout (Rubenson et al. 2004). These findings indicate that conscious efforts to appeal to voters when they are young may set in motion a trend toward increased civic engagement over the course of the lifecycle. Aware of the need to stimulate voter turnout, for example, the three main political parties in the U.K. have stepped up their efforts to recruit young people, involve them in policy formulation, and assimilate the opinions of their youth sections into the mainstream party machinery. Nonetheless, the shape of these initiatives varies substantially: while young people serve primarily as campaign foot soldiers in the Conservative Party, they have official representatives in the two main policy-making structures of the Labour Party and enjoy a privileged status among the Liberal Democrats in terms of resources and influence within the party (Russell 2005).

The impact of these measures, and importance of cross-party variations, is as yet unknown. However, there is evidence to suggest that more active steps to promote young people within the parties may be an effective strategy for increasing their levels of political involvement. In a series of focus groups and interviews with individuals aged 16 to 25 in Birmingham, researchers discover that young people are not so much politically apathetic as disillusioned about how politics is organized. In fact, many of their respondents believe that they are excluded from, or marginalized within, politics because they are young, causing them to express low levels of political efficacy. Further, they made comments reflecting the fact that they felt that young people were poorly represented at local and national levels, a pattern that they believe leads issues important to young people - like teenage sex, pregnancy, and parenthood; problems in accessing employment, training, or education; and lack of resources within local communities for young people - inadequately addressed (O'Toole, Marsh, and Jones 2003).

Comparative research on these questions is limited to cross-national studies substantiating claims about the important of generational change in shaping broad patterns of voter turnout over time (Franklin, Lyons, and Marsh 2004). This work, however, also observes broad variations in turnout across countries, patterns which may change over time, the authors suggest, due to changes in the character of elections or shifts in the proportion of the electorate that pays attention to the character that elections have. While vague, these possibilities intimate that, if parties focus on improving the descriptive 
representation of young people, these changes in the representative profiles of political institutions may have potentially important effects on youth civic engagement. However, the only evidence in support of this account is largely indirect. In a study focused on the symbolic impact of women's presence, the authors suggest that the effects of descriptive representation may be greatest among young people, because their attitudes and actions are more malleable and therefore more open to cues from the political environment than those of older citizens. Their hypothesis is confirmed, as they find that as the percentage of women in parliament increases, both boys and girls are more likely to express an intention to be active in politics, although the effect is greater among girls (Wolbrecht and Campbell 2007). Although this study does not address the symbolic effects of youth representation, it reveals that the young are susceptible to external cues, indicating that it may be worth investigating in a comparative fashion how patterns of youth representation may be related to broader trends in civic engagement across countries and over time.

\section{Data and Methods}

In the light of the previous literature, the research is designed with three goals in mind: (1) to compare the effects of sex and age at the elite level with disparities in civic engagement among these social sectors, rather than focusing upon each in isolation; (2) to examine these effects in cross-national perspective; and (3) to analyze both attitudinal and behavioral measures of civic engagement. The approach therefore seeks to establish robust generalizations about the impact of descriptive representation upon mass civic engagement, tested through alternative indicators, different social sectors, and diverse contexts.

The previous literature suggests a series of hypotheses which can be explored. The core proposition of this study is that descriptive representation by social sectors in legislative elites will serve to mobilize subsequent civic engagement among similar social sectors in the electorate. This claim suggests a series of primary hypotheses which can be explored with the empirical evidence.

First, in terms of attitudes which mobilize groups to become more active in public affairs and civic life, such as cognitive awareness and political interest, the theory predicts:

H1.1: More female representatives in the national parliament will increase political interest among women in the electorate.

H1.2: A higher proportion of younger representatives in the national parliament will strengthen young people's political interest at the mass level.

These are important attitudes: knowing and caring about politics are steps prior to more active forms of political participation (Verba, Burns, and Schlozman 1997). In addition, it is well established that women are significant less interested in politics than men, a gender gap which is strongest in developing societies but which remains apparent even in contemporary post-industrial nations (Inglehart 1979; Inglehart and Norris 2003). However, if the number of female office-holders grows, women as a group may come to perceive these legislatures as becoming more inclusive and responsive, and this could be expected to generate greater political interest and awareness among women in the electorate. A similar logic may also lead increased descriptive representation to stimulate political interest among the young.

In addition to these effects, the theory predicts in terms of political behavior:

H2.1: More female representatives in the national parliament will strengthen political activism among women in the electorate.

H2.2: A higher proportion of younger representatives in the national parliament will boost political activism among younger voters. 
A logic similar to the one outlined above suggests that where people believe that members of elected bodies reflect shared experiences and values, and where institutions are seen as more open and responsive, this should encourage traditionally marginalized groups to become more active in public affairs. This may occur through such activities as voting, becoming active in political parties and voluntary associations, and engaging in peaceful demonstrations. However, as political participation makes stronger demands of time, effort and resources than simply monitoring political events, any effects are likely to be weaker on behavior than on attitudes.

The composition of parliaments

To explore these issues, this study draws upon a global classification of the social composition of national parliaments. For the proportion of women in the lower house of parliament, the analysis drew upon the Inter-Parliamentary Union database on Women in Parliament Worldwide, in the latest election to 2005.The age profile of members of the lower house of parliament in 66 nations was compiled for the most recent election for which data was available in the period 2000-2007 from annual volumes of the Chronicle of Parliamentary Elections published by the Inter-Parliamentary Union.

\section{Mass attitudes and behavior}

The broadest cross-national coverage of mass-level data on civic engagement is available from the pooled World Values Survey/European Values Survey (WVS), a global investigation of socio-cultural and political change conducted in five waves from 1981 to 2007. This project has carried out representative national surveys of the basic values and beliefs of the publics in more than 90 independent countries, containing over $88 \%$ of the world's population and covering all six inhabited continents. It builds on the European Values Survey, first carried out in 22 countries in 1981. A second wave of surveys was completed in 43 countries 1990-1991. A third wave was carried out in 55 nations in 1995-1996, and a fourth wave, in 59 countries, took place in 1999-2001. The fifth wave covering 55 countries was conducted in 2005-2007. ${ }^{1}$

The WVS survey includes some of the most affluent market economies in the world, such as the U.S., Japan, and Switzerland, with per capita annual incomes over $\$ 40,000$, together with middle-level countries including Mexico, Slovakia, and Turkey, as well as poorer agrarian societies, such as Ethiopia, Mali, and Burkina Faso, with per capita annual incomes of $\$ 200$ or less. There are also significant variations in levels of human development in the countries under comparison, as monitored by the UNDP Human development Index combining per capita income with levels of education, literacy and longevity. Some smaller nations also have populations below one million, such as Malta, Luxembourg and Iceland, while at the other extreme both India and China have populations of well over one billion people.

The survey contains older democracies such as Australia, India and the Netherlands, newer democracies including El Salvador, Estonia and Taiwan, and autocracies such as China, Zimbabwe, Pakistan, and Egypt. The transition process also varies markedly: some nations have experienced rapid process of democratization during the 1990s; today the Czech Republic, Latvia, and Argentina currently rank as high on political rights and civil liberties as Belgium, the United States, and the Netherlands, all of which have a long tradition of democratic governance. ${ }^{2}$ The survey also includes some of the first systematic data on public opinion in several Muslim states, including Arab countries such as Jordan, Iran, Egypt, and Morocco, as well as in Indonesia, Iran, Turkey, Bangladesh, and Pakistan. The most comprehensive coverage comes from Western Europe and North America, where public opinion surveys have the longest tradition, but countries are included from all world regions, including Sub Saharan Africa. 


\section{Measures of civic engagement}

Several attitudinal and behavioral measures of the multidimensional concept of civic engagement were selected from the World Values Survey, to see whether the results prove robust irrespective of the particular indicator which is tested. Details are provided in the technical appendix. Disparities or gaps in civic engagement are measured by the difference between the proportion of men versus women and older and younger citizens within each country.

To analyze attitudinal mobilization, the study compares standard items measuring levels of political interest and the importance of politics (WVS Waves 1-5). Both of these are indicative of a proclivity to pay attention to civic affairs and these are strong predictors of political knowledge and awareness, as well as use of the news media.

To explore political behavior, the study monitors self-reported voting turnout in the most recent national parliamentary election (WVS Wave 5). Voting participation is atypical of other forms of activism, as the most ubiquitous but also the least demanding form of involvement. Nevertheless it is also basic to citizenship in democratic states, public concern about falling turnout is common in many countries, and there remain substantial voting gaps across each of the sectors under comparison (Blais 2000; Franklin 2004). Given renewed interest in issues of social capital and voluntary work within community organizations (Putnam 2000; O'Neill 2005), the study also analyzes associational membership, a composite scale from the WVS involving active membership in a series of nine organizations including churches, sports clubs, parties, and unions (WVS Wave 5). Moreover work within these community groups may also provide valuable experience and networks which lead to the pursuit of elected office (Rosenstone and Hanson 1993). Lastly the study also looks at participation in peaceful demonstrations, as an indicator of engagement in protest politics. Replicating the models using alternative indicators of civic engagement helps to check the robustness of the major findings.

\section{Multilevel models}

The study employs multilevel models to explore the relationship between descriptive representation in the lower or single houses of national parliaments and patterns of civic engagement among citizens. A representative sample of individual respondents (level 1 ) is nested within national-level contexts (level 2). The multilevel models control for many other national-level factors expected to influence both civic engagement and social representation, including the historical experience of democracy. Models were also tested controlling for economic development (measured by per capita income). These coefficients were not significant and they were eventually dropped to avoid problems of multicollinearity with the measure of democratization. The models also control for individual-level factors commonly associated in the research literature with civic engagement, including education, household income, labor force participation, marital status, and the strength of religiosity. The use of multilevel regression analysis is the most appropriate technique which uses restricted maximum likelihood techniques (REML) to estimate direct and cross-level effects for hierarchical data. Individual respondents are thus grouped into nation-states. Each nation-state has a different set of parameters for the random factors, allowing intercepts and slopes to vary by nation.

\section{Analysis and Results}

Table 1 presents the key results concerning women's representation. The models first enter the proportion of women in parliament in each country, then the sex of electors, and the interaction effect between these factors. The models also include the gender equality scale, to control for the effects of more egalitarian cultures; the battery of standard demographic and social controls at the individual level; and the country's length of experience of democracy at the national level. 
[Table 1 about here]

The results in Table 1 show strikingly consistent results across four of the five indicators of civic engagement, confirming our primary hypotheses concerning sex. Firstly, in the comparison of political interest, the importance of politics, associational membership, and demonstrating, the proportion of women in the national parliament has no significant impact by itself. Secondly, in each of these dimensions, women proved significantly less engaged than men (shown by the negative coefficients). This confirms the continued existence of gender gaps in political participation which have been widely established in the research literature for many decades. But, thirdly, and most importantly, the interaction effect between the proportion of women in parliament and gender reverses this pattern, suggesting that in countries where there are more women in elected office, women in the electorate are significantly more likely to be interested and active in politics than men. Moreover these effects are apparent even after controlling for attitudes towards gender equality, suggesting that the association is not simply the spurious product of traditional or egalitarian cultures.

The main exception to these observations concerns voting participation, where there is no significant gender gap in participation. Many countries have seen a gradual closure of differences in men and women's voting turnout, while in recent decades some such as the United States have even experienced higher levels of voting participation among female electors (Norris 2001; Norris 2004).

The remaining controls act in a manner which is largely consistent with expectations from the general literature on civic engagement, for example education and household income are strongly related to greater participation and awareness of politics, reflecting the common socioeconomic bias long evident among activists. Age, marital status, labor force participation, and the strength of religiosity are also positively related to most of the indicators of civic engagement, with the exception of demonstrations, which are more common among the young, single, and non-religious.

[Table 2 about here]

For comparison, Table 2 presents the key results of comparable models by age. Among the general public, age has the expected effect on civic engagement, confirming that the older population are significantly more likely to express interest in politics and to regard this arena as important, as well as being more likely to cast a voting ballot and to join associations, although they are less likely to demonstrate. Most strikingly, however, the effect of the interaction between the representation of younger members of parliament and the age of respondents in the general electorate shows that the age gap in attitudes and in associational membership becomes insignificant. This suggests that younger people are usually less politically interested and engaged in voluntary groups and clubs, as many previous studies report, but this is not the case in countries with greater representation of younger people in elected office. Nevertheless younger citizens continue to be less likely to cast a ballot, and the age gap remains both significant and substantively large, as many previous commentators have noted. The size of the age gap in voting participation shrinks, due to the interaction effect, but continues to prove significant. The remaining control variables perform as expected and confirm the standard social disparities in civic engagement, noted earlier.

\section{Conclusion and Discussion}

The issue of descriptive representation reflects one of the oldest traditions, where socially diverse and inclusive elected bodies are thought important for the quality of democracy. Indeed after the Norman Invasion of 1066, the Great Council of England, which later evolved into the parliamentum, brought together barons and prelates from all counties. Subsequent parliamentary bodies in Western Europe were commonly founded on the ancient principle of geographic representation, where local delegates came together in a common national assembly. During the $19^{\text {th }}$ century, issues of social status and class 
politics were critical for arguments about expanding the franchise and thus the inclusion of working class representatives in parliamentary elites. Ideas that elected bodies also need to reflect the voices of women, major linguistic, religious and racial ethnic groups, and younger generations, reflect more distinctly modern notions of descriptive representation.

The widespread assumption that descriptive representation will influence civic engagement in the mass public, while common in popular and scholarly commentary, has been subjected to only limited systematic scrutiny. The major findings of this study are that the propensity for women to be less politically engaged than men, according to many attitudinal and behavioral indicators, continues to be evident in contemporary societies. Nevertheless this traditional gender gap in civic engagement is not simply reduced, but it is actually reversed, in societies where women are more fully represented in leadership roles in national parliaments. In the light of theories about the role and function of social stereotypes, these results are consistent with the argument that the inclusion of women in elected office provides visible role models and social cues about the responsiveness and openness of the political system that encourages more women to become interested and active in grassroots politics.

Comparable analysis of the effects of including younger members in parliament suggests a more complex picture, but again this reinforces the claim that descriptive representations matters for masslevel civic engagement. In general, there is a well-established skew towards political participation and interest among the middle-aged and older populations, a pattern which has caused considerable concern among policymakers and scholars. In societies where the composition of parliament includes younger members, however, the age gaps in political interest and associational membership fade away and become insignificant, although an important age-disparity in voting turnout remains evident.

The results also lend weight to the thesis that elected bodies which look more like the population from which they are drawn are more likely to be regarded as responsive; younger groups are not more apathetic or passive in countries where the age profile of national parliaments is seen to reflect their generation. One important implication of this finding concerns the gradual aging of the U.S. Congress where the proportion of younger members of the House of Representatives (under 40 years old) drops from one fifth in 1981 to just 5\% today (Stanley and Niemi 2010). During the same decades, the proportion of younger U.S. Senators plummeted from $10 \%$ to nil. This trend may be one explanation helping to explain any erosion of turnout which has occurred among the younger generation of Americans during these years.

Certain important qualifications, however, should be noted when interpreting these results. Empirical studies about the impact of descriptive representation need to carefully disentangle the direction of causality. At least two alternative interpretations of the results remain possible. First, if operating as a top-down relationship, as argued in this paper, greater visibility for representatives drawn from certain visible minorities in parliament could plausibly encourage citizens from these groups to become more engaged in civic affairs. The inclusion of minorities in leadership positions, the study theorizes, serve as important role models for citizens, as well as making the legislature appear more open and responsive to the social needs and politically priorities of previously marginalized groups. Social stereotypes are widespread in psychological perceptions, with the social cues provided by sex and age making leadership elites drawn from these sectors appear more like "one of us."

Yet alternatively, however, there is another way of understanding the association, if a bottom-up process is operating. It remains possible that the greater participation of women and young people in local parties, civic associations, and election campaigns could help to generate the organizational networks, resources, and political experience which facilitate the subsequent successful pursuit of elected office. Candidate selection processes choose representatives with skills and backgrounds which are perceived as most suitable for parliamentary work (Norris and Lovenduski 1995). More women and 
young people engaged in grassroots community politics could therefore potentially expand the pool of eligible candidates drawn from these social sectors, and thus influence the composition of parliamentary elites.

It is not possible to rule out, or indeed to rule in, the bottom up thesis from the evidence available in this study. Further longitudinal case study research is needed which could study this process as a temporal sequence, to resolve these issues. For example, any major changes in the social composition of political elites can be employed as 'natural experiments' to see whether these generate subsequent persistent shifts in civic engagement among relevant social sectors. In the United States, for example, will the election of Barack Obama, the first African American president, lead to an enduring change in political participation and interest among African American electors? Similarly the entry of record numbers of women MPs following the successful implementation of gender quotas, such the 1997 British general election, provide 'before' and 'after' test cases to monitor changes among women and men in the mass electorate. Moreover an additional strategy would be to gather cross-national data on the composition of parliaments during earlier decades, to test whether there are any significant lagged effects on contemporary levels of civic engagement.

In addition, the effects of descriptive representation also need to be extended in future research to understand whether similar patterns operate for racial and ethnic minorities. Research has documented relatively low levels of civic engagement among these groups, although the vast majority of this work focuses on African-Americans and Latinos in the U.S. (Abramson 1972; Long 1978; Michelson 2000). There is more limited cross-national evidence but studies in other established democracies nonetheless reach similar conclusions, finding that members of minority racial and ethnic groups are much less likely to turn out to vote (Lapp 1999; Solomos 1980). Comparative literature on these questions is less extensive than research on sex and age, however, in part because "race" and "ethnicity" are among the most complex and elusive terms to define and measure clearly for cross-national research (cf. Hughes 2008). Many scholars argue that these identities are best understood as social constructs with deep cultural and psychological roots based on national, cultural-linguistic, racial, or religious backgrounds (Anderson 1983; Billig 1995; Gellner 1983).

The increased election of minority officials, moreover, has led some scholars to explore whether changes in levels of descriptive representation are associated with increased rates of civic engagement among members of minority groups. The available literature on this topic focuses mainly on the U.S. case, although one study compares trends in the U.S. and New Zealand (Banducci, Donovan, and Karp 2004). The literature on the U.S., addressing the impact of minority office-holders on levels of political alienation among group members, finds that minority constituents tend to be less politically alienated and more politically active in cities governed by minority mayors and districts reserved for members of minority groups (Bobo and Gilliam 1990; Barreto, Segura, and Woods 2004). However, it remains to be seen in future research whether findings concerning the impact of ethnic representation in the U.S. are also apparent in a broader comparative perspective.

Another issue for the research agenda concerns the impact of political institutions in conditioning any effects. In particular, Carey and Shugart (1995) offer reasons why there are stronger incentives to cultivate a personalistic vote in electoral systems using single member districts, including focusing on the personal characteristics and background experience of candidates for elected office. By contrast, party-centered votes are expected to be more common in multimember districts, such as party list PR. It follows that any impact from descriptive representation may be stronger in the former context. In addition other institutional contrasts may be expected to influence the impact of descriptive representation, such as in the availability of national or localized information sources available to voters, the structure of parliamentary or presidential elections, and the strength of party discipline and 
programmatic parties within the legislature. The use of positive action quotas for candidates may also prove important, especially if this suddenly brings radical changes into the composition of parliamentary elites (Krook 2009; Krook and O'Brien forthcoming). There are therefore many reasons why crossnational comparisons therefore need to explore the impact of political institutions upon the effects of descriptive representation.

All these areas expand the issues which could be considered to understand this phenomenon more fully. Nevertheless the cross-national evidence presented in this study serves to broaden the comparative basis for generalizing about the representation of women and young people in a wide variety of institutional contexts and world regions. The results generally support the argument that descriptive representation in parliamentary elites has broader consequences for understanding long-standing inequalities in civic engagement, and thus also for representative democracy. This claim is important for normative debates, especially providing another reason for advocating positive action strategies, such as quotas, designed to bring more politically marginalized groups into public office. More inclusive and diverse parliamentary bodies may be important symbolically for democratic legitimacy and human rights, as well as having substantive consequences for the public policy agenda and the representation of group interests. The conclusions of this study suggests that descriptive representation is also important for strengthening the engagement of all social sectors in the electorate - including women and men and young and old - in democratic politics and public affairs. 
Table 1: Multilevel model predicting civic engagement by gender

\begin{tabular}{|c|c|c|c|c|c|}
\hline & \multicolumn{2}{|c|}{ POLITICAL ATTITUDES } & \multicolumn{3}{|c|}{ POLITICAL BEHAVIOR } \\
\hline & $\begin{array}{l}\text { Political } \\
\text { interest }\end{array}$ & $\begin{array}{r}\text { Importance of } \\
\text { politics }\end{array}$ & Voted & $\begin{array}{r}\text { Associational } \\
\text { member }\end{array}$ & Demonstrated \\
\hline \multicolumn{6}{|l|}{ PREDICTOR VARIABLES } \\
\hline Proportion of women MPs & $\begin{array}{r}.079 \\
(.048)\end{array}$ & $\begin{array}{r}.019 \\
(.042)\end{array}$ & $\begin{array}{r}.027 \\
(.030)\end{array}$ & $\begin{array}{r}.454 \\
(1.11)\end{array}$ & $\begin{array}{r}. .033 \\
(.061)\end{array}$ \\
\hline Gender (female $=1$, male $=0$ ) & $\begin{array}{r}-.134 * * * \\
(.003)\end{array}$ & $\begin{array}{r}-.079 * * * \\
(.003)\end{array}$ & $\begin{array}{r}.005 \\
(.002)\end{array}$ & $\begin{array}{r}-.239 * * * \\
(.060)\end{array}$ & $\begin{array}{r}-.093 * * * \\
(.003)\end{array}$ \\
\hline $\begin{array}{l}\text { Proportion of women } \\
\text { MPs*Gender }\end{array}$ & $\begin{array}{r}.008 * * * \\
(.002)\end{array}$ & $\begin{array}{r}.014 * * * \\
(.002)\end{array}$ & $\begin{array}{r}.001 \\
(.002)\end{array}$ & $\begin{array}{r}.217 * * * \\
(.052)\end{array}$ & $\begin{array}{r}.023^{* * *} \\
(.002)\end{array}$ \\
\hline \multicolumn{6}{|l|}{$\begin{array}{l}\text { INDIVIDUAL-LEVEL } \\
\text { CONTROLS }\end{array}$} \\
\hline Gender equality scale & $\begin{array}{r}.045 * * * \\
(.003)\end{array}$ & $\begin{array}{r}.043 * * * \\
(.003)\end{array}$ & $\begin{array}{r}.020 * * * \\
(.004)\end{array}$ & $\begin{array}{r}.182 \\
(.098)\end{array}$ & $\begin{array}{r}.071 * * * \\
(.004)\end{array}$ \\
\hline Age (years) & $\begin{array}{r}.098 * * * \\
(.003)\end{array}$ & $\begin{array}{r}.076 * * * \\
(.003)\end{array}$ & $\begin{array}{r}.112 * * * \\
(.002)\end{array}$ & $\begin{array}{r}.547 * * * \\
(.067)\end{array}$ & $\begin{array}{r}-.036 * * * \\
(.003)\end{array}$ \\
\hline $\begin{array}{l}\text { Household income 10-pt } \\
\text { scale }\end{array}$ & $\begin{array}{r}.049 * * * \\
(.003)\end{array}$ & $\begin{array}{r}.024 * * * \\
(.003)\end{array}$ & $\begin{array}{r}.009 * * * \\
(.002)\end{array}$ & $\begin{array}{r}.905 * * * \\
(.067)\end{array}$ & $\begin{array}{r}.029 * * * \\
(.003)\end{array}$ \\
\hline Education 9-pt scale & $\begin{array}{r}.196 * * * \\
(.003)\end{array}$ & $\begin{array}{r}.154 * * * \\
(.003)\end{array}$ & $\begin{array}{r}.046 * * * \\
(.003)\end{array}$ & $\begin{array}{r}1.91 * * * \\
(.070)\end{array}$ & $\begin{array}{r}.215^{* * *} \\
(.003)\end{array}$ \\
\hline Labor force participation & $\begin{array}{l}.007 * \\
(.003)\end{array}$ & $\begin{array}{r}-.004 \\
(.003)\end{array}$ & $\begin{array}{r}.035 * * * \\
(.002)\end{array}$ & $\begin{array}{r}.771 * * * \\
(.066)\end{array}$ & $\begin{array}{r}.049 * * * \\
(.003)\end{array}$ \\
\hline Marital status & $\begin{array}{r}.011 * * * \\
(.003)\end{array}$ & $\begin{array}{l}.007^{*} \\
(.003)\end{array}$ & $\begin{array}{r}.046 * * * \\
(.002)\end{array}$ & $\begin{array}{r}.029 \\
(.061)\end{array}$ & $\begin{array}{r}-.017 * * * \\
(.003)\end{array}$ \\
\hline Strength of religiosity & $\begin{array}{r}.018 * * * \\
(.003)\end{array}$ & $\begin{array}{r}.023 * * * \\
(.003)\end{array}$ & $\begin{array}{l}-.001 \\
(.003)\end{array}$ & $\begin{array}{r}1.28 * * * \\
(.075)\end{array}$ & $\begin{array}{r}-.076 * * * \\
.004)\end{array}$ \\
\hline \multicolumn{6}{|l|}{ NATIONAL-LEVEL CONTROLS } \\
\hline $\begin{array}{l}\text { Historical experience of } \\
\text { democratization }\end{array}$ & $\begin{array}{l}-.002 \\
(.001)\end{array}$ & $\begin{array}{l}-.003 \\
(.001)\end{array}$ & $\begin{array}{l}-.001 \\
(.001)\end{array}$ & $\begin{array}{r}.044 \\
(.050)\end{array}$ & $\begin{array}{r}.004 \\
(.002)\end{array}$ \\
\hline Constant (intercept) & 2.49 & 2.47 & .790 & 5.98 & .755 \\
\hline Schwartz BIC & 266,26 & 278,139 & 22,981 & 196,485 & 259,879 \\
\hline N. respondents & 101,357 & 103,423 & 25,423 & 26,837 & 91,557 \\
\hline N. nations & 39 & 39 & 16 & 18 & 37 \\
\hline
\end{tabular}

Notes: All independent variables were standardized using mean centering (z-scores). Models present the results of the REML multilevel regression models including the beta coefficient, (the standard error below in parenthesis), and the significance. The items are listed in the Technical Appendix. P.* $>.05^{* *}>.01 * * *>001$

Source: Pooled World Values Survey 1981-2007. 
Table 2: Multilevel model predicting civic engagement by age

\begin{tabular}{|c|c|c|c|c|c|}
\hline & \multicolumn{2}{|c|}{ POLITICAL ATTITUDES } & \multicolumn{3}{|c|}{ POLITICAL BEHAVIOR } \\
\hline & $\begin{array}{l}\text { Political } \\
\text { interest }\end{array}$ & $\begin{array}{r}\text { Importance of } \\
\text { politics }\end{array}$ & Voted & $\begin{array}{r}\text { Associational } \\
\text { member }\end{array}$ & Demonstrated \\
\hline \multicolumn{6}{|l|}{ PREDICTOR VARIABLES } \\
\hline Proportion of younger MPs & $\begin{array}{r}.002 \\
(.005)\end{array}$ & $\begin{array}{r}.002 \\
(.005)\end{array}$ & $\begin{array}{r}.068^{* * *} \\
(.004)\end{array}$ & $\begin{array}{r}-.478 * * * \\
(1.14)\end{array}$ & $\begin{array}{r}-.047^{* * *} \\
(.006)\end{array}$ \\
\hline Age (years) & $\begin{array}{r}.099 * * * \\
(.006)\end{array}$ & $\begin{array}{r}.079 * * * \\
(.003)\end{array}$ & $\begin{array}{r}.180 * * * \\
(.005)\end{array}$ & $\begin{array}{r}.121 \\
(.132)\end{array}$ & $\begin{array}{r}-.061 * * * \\
(.007)\end{array}$ \\
\hline $\begin{array}{l}\text { Proportion of younger } \\
\text { MPs*Age }\end{array}$ & $\begin{array}{r}.002 \\
(.006)\end{array}$ & $\begin{array}{r}.007 \\
(.006)\end{array}$ & $\begin{array}{r}.054 * * * \\
(.005)\end{array}$ & $\begin{array}{c}.214 \\
(.135)\end{array}$ & $\begin{array}{r}.076 * * * \\
(.007)\end{array}$ \\
\hline \multicolumn{6}{|l|}{$\begin{array}{l}\text { INDIVIDUAL-LEVEL } \\
\text { CONTROLS }\end{array}$} \\
\hline Gender (female $=1$, male $=0$ ) & $\begin{array}{r}-.129 * * * \\
(.003)\end{array}$ & $\begin{array}{r}-.075 * * * \\
(.003)\end{array}$ & $\begin{array}{r}.006 * * \\
(.002)\end{array}$ & $\begin{array}{r}-.215 * * * \\
(.059)\end{array}$ & $\begin{array}{r}-.088 * * * \\
(.003)\end{array}$ \\
\hline $\begin{array}{l}\text { Household income } 10-p t \\
\text { scale }\end{array}$ & $\begin{array}{r}.049 * * * \\
(.003)\end{array}$ & $\begin{array}{r}.024 * * * \\
(.003)\end{array}$ & $\begin{array}{r}.012 * * * \\
(.002)\end{array}$ & $\begin{array}{r}.873^{* * *} \\
(.067)\end{array}$ & $\begin{array}{r}.025^{* * *} \\
(.003)\end{array}$ \\
\hline Education 9-pt scale & $\begin{array}{r}.202 * * * \\
(.003)\end{array}$ & $\begin{array}{r}.161 * * * \\
(.003)\end{array}$ & $\begin{array}{r}.046 * * * \\
(.003)\end{array}$ & $\begin{array}{r}1.96 * * * \\
(.069)\end{array}$ & $\begin{array}{r}.228 * * * \\
(.003)\end{array}$ \\
\hline Labor force participation & $\begin{array}{l}.009 * \\
(.003)\end{array}$ & $\begin{array}{r}-.002 \\
(.003)\end{array}$ & $\begin{array}{r}.030 * * * \\
(.002)\end{array}$ & $\begin{array}{r}.822 * * * \\
(.066)\end{array}$ & $\begin{array}{r}.040 * * * \\
(.003)\end{array}$ \\
\hline Marital status & $\begin{array}{r}.012 * * * \\
(.003)\end{array}$ & $\begin{array}{r}.005 \\
(.003)\end{array}$ & $\begin{array}{r}.037 * * * \\
(.002)\end{array}$ & $\begin{array}{r}.047 \\
(.061)\end{array}$ & $\begin{array}{r}-.032 * * * \\
(.003)\end{array}$ \\
\hline Strength of religiosity & $\begin{array}{r}.018 * * * \\
(.003)\end{array}$ & $\begin{array}{r}.023 * * * \\
(.003)\end{array}$ & $\begin{array}{r}-.001 \\
(.003)\end{array}$ & $\begin{array}{r}1.29 * * * \\
(.075)\end{array}$ & $\begin{array}{r}-.077 * * * \\
(.004)\end{array}$ \\
\hline \multicolumn{6}{|l|}{ NATIONAL-LEVEL CONTROLS } \\
\hline $\begin{array}{l}\text { Historical experience of } \\
\text { democratization }\end{array}$ & $\begin{array}{l}-.001 \\
(.001)\end{array}$ & $\begin{array}{l}-.002 \\
(.001)\end{array}$ & $\begin{array}{l}-.001 \\
(.001)\end{array}$ & $\begin{array}{c}.061 \\
(.034)\end{array}$ & $\begin{array}{r}.004 * * \\
(.002)\end{array}$ \\
\hline Constant (intercept) & 2.40 & 2.47 & .790 & 4.95 & .798 \\
\hline Schwartz BIC & 271,478 & 283,330 & 22,829 & 196,485 & 265,085 \\
\hline N. respondents & 103,146 & 105,307 & 25,465 & 26,877 & 93,261 \\
\hline N. nations & 40 & 40 & 17 & 19 & 38 \\
\hline
\end{tabular}

Notes: All independent variables were standardized using mean centering (z-scores). Models present the results of the REML multilevel regression models including the beta coefficient, (the standard error below in parenthesis), and the significance. The items are listed in the Technical Appendix. P.*>.05**>.01***>.001 Source: Pooled World Values Survey 1981-2007. 
Figure 1: The proportion of younger members of parliament (under forty), 2000-2007

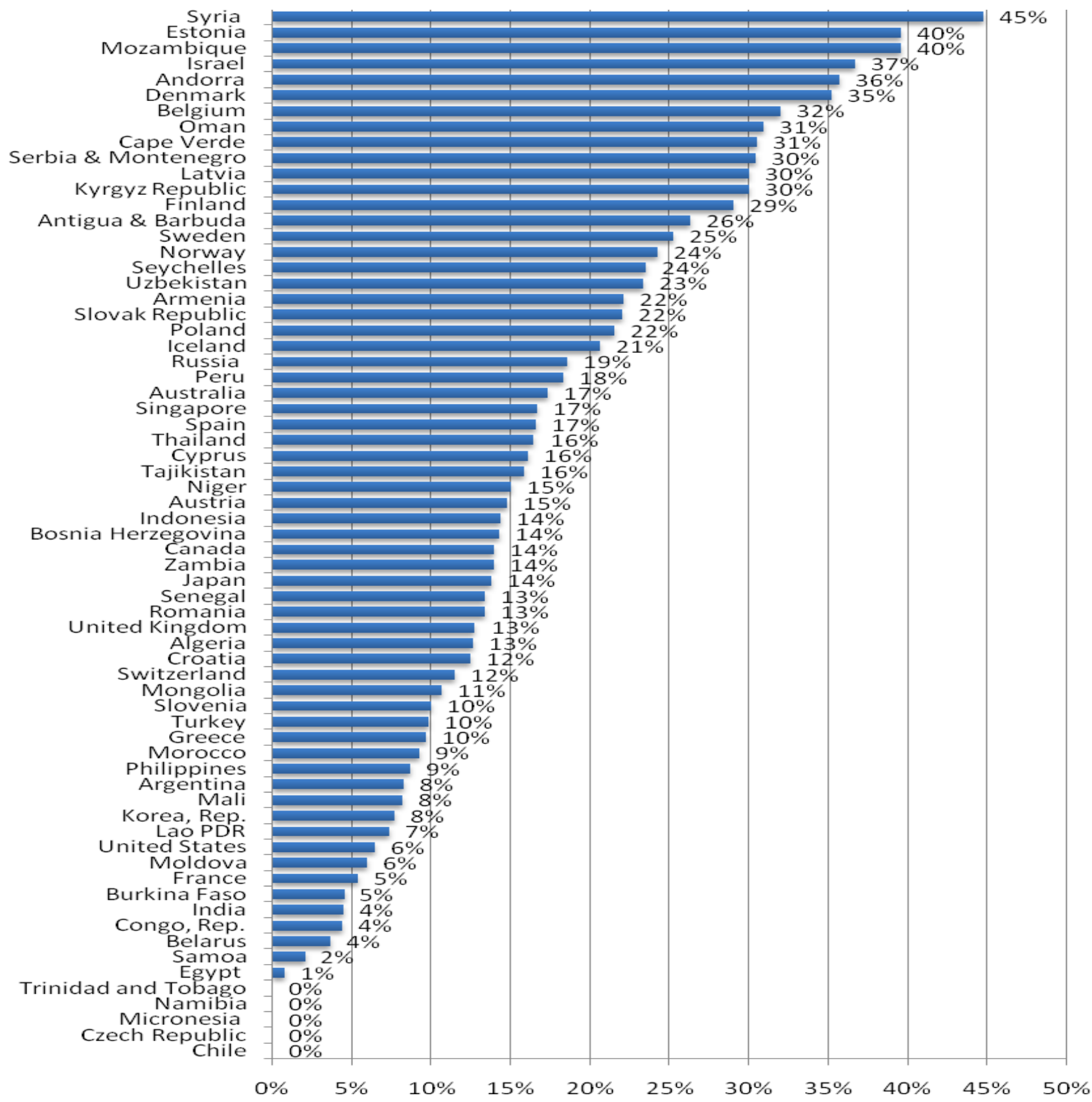

Note: The proportion of members of the lower house of parliament under 40 years old, latest election 2000-2007.

Source: Calculated for 66 national parliaments from annual volumes of the Chronicle of Parliamentary Elections. Geneva: Inter-Parliamentary Union. 
Table A1. Technical appendix: Descriptive representation in the lower house of parliament

\begin{tabular}{|c|c|c|c|}
\hline Nation & Women MPs & $\begin{array}{r}\text { Younger MPs } \\
\text { (under 40) }\end{array}$ & Older MPs $(60+)$ \\
\hline & $\%$ & $\%$ & $\%$ \\
\hline Afghanistan & 27.7 & & \\
\hline Albania & 7.1 & & \\
\hline Algeria & 7.7 & 12.6 & 9.8 \\
\hline Andorra & 28.6 & 35.7 & 0.0 \\
\hline Angola & 15.0 & & \\
\hline Antigua \& Barbuda & 10.5 & 26.3 & 5.3 \\
\hline Argentina & 40.0 & 8.2 & 20.8 \\
\hline Armenia & 9.2 & 22.1 & 7.6 \\
\hline Australia & 26.7 & 17.3 & 9.3 \\
\hline Austria & 32.8 & 14.8 & 4.9 \\
\hline Azerbaijan & 11.4 & & \\
\hline Bahamas & 12.2 & & \\
\hline Bahrain & 2.5 & & \\
\hline Bangladesh & 15.0 & & \\
\hline Barbados & 13.3 & & \\
\hline Belarus & 29.1 & 3.6 & 6.4 \\
\hline Belgium & 35.3 & 32.0 & 4.0 \\
\hline Belize & 3.3 & & \\
\hline Benin & 10.8 & & \\
\hline Bhutan & 2.7 & & \\
\hline Bolivia & 16.9 & & \\
\hline Bosnia \& Herzegovina & 11.9 & 14.3 & 4.8 \\
\hline Botswana & 11.1 & & \\
\hline Brazil & 9.0 & & \\
\hline Brunei Darussalam & 0.0 & & \\
\hline Bulgaria & 21.7 & & \\
\hline Burkina Faso & 15.3 & 4.5 & 9.9 \\
\hline Burundi & 30.5 & & \\
\hline Cambodia & 19.5 & & \\
\hline Cameroon & 13.9 & & \\
\hline Canada & 21.3 & 14.0 & 19.5 \\
\hline Cape Verde & 18.1 & 30.6 & 0.0 \\
\hline Central African Republic & 10.5 & & \\
\hline Chad & 5.2 & & \\
\hline Chile & 15.0 & 0.0 & 53.1 \\
\hline China & 20.6 & & \\
\hline Colombia & 8.4 & & \\
\hline Comoros & 3.0 & & \\
\hline Congo, Democratic Republic & 7.3 & & \\
\hline Congo, Republic of & 8.4 & 4.4 & 10.9 \\
\hline Costa Rica & 36.8 & & \\
\hline Cote D'Ivoire & 8.9 & & \\
\hline Croatia & 20.9 & 12.4 & 11.8 \\
\hline Cuba & 36.0 & & \\
\hline Cyprus & 14.3 & 16.1 & 14.3 \\
\hline Czech Republic & 15.5 & 0.0 & 19.8 \\
\hline Denmark & 38.0 & 35.2 & 15.6 \\
\hline Djibouti & 13.8 & & \\
\hline Dominica & 16.1 & & \\
\hline
\end{tabular}




\begin{tabular}{|c|c|c|c|}
\hline Nation & Women MPs & $\begin{array}{r}\text { Younger MPs } \\
\text { (under 40) }\end{array}$ & Older MPs $(60+)$ \\
\hline Dominican Republic & 19.7 & & \\
\hline Ecuador & 25.0 & & \\
\hline Egypt & 1.8 & 0.8 & 54.9 \\
\hline El Salvador & 16.7 & & \\
\hline Equatorial Guinea & 18.0 & & \\
\hline Eritrea & 22.0 & & \\
\hline Estonia & 20.8 & 39.6 & 6.9 \\
\hline Ethiopia & 21.9 & & \\
\hline Fiji & 18.2 & & \\
\hline Finland & 41.5 & 29.0 & 11.5 \\
\hline France & 16.7 & 5.4 & 26.2 \\
\hline Gabon & 9.4 & & \\
\hline Gambia & 9.4 & & \\
\hline Georgia & 31.6 & & \\
\hline Germany & 10.9 & & \\
\hline Ghana & 14.7 & & \\
\hline Greece & 14.7 & 9.7 & 17.7 \\
\hline Grenada & 26.7 & & \\
\hline Guatemala & 12.0 & & \\
\hline Guinea & 19.3 & & \\
\hline Guinea-Bissau & 18.0 & & \\
\hline Guyana & 29.0 & & \\
\hline Haiti & 4.1 & & \\
\hline Honduras & 23.4 & & \\
\hline Hungary & 11.1 & & \\
\hline Iceland & 33.3 & 20.6 & 15.9 \\
\hline India & 11.6 & 4.5 & 44.5 \\
\hline Indonesia & 4.1 & 14.4 & 16.0 \\
\hline Iran & 25.5 & & \\
\hline Iraq & 13.3 & & \\
\hline Ireland & 14.2 & & \\
\hline Israel & 17.3 & 36.7 & 44.2 \\
\hline Italy & 13.3 & & \\
\hline Jamaica & 9.4 & & \\
\hline Japan & 6.4 & 13.8 & 25.2 \\
\hline Jordan & 15.9 & & \\
\hline Kazakhstan & 7.2 & & \\
\hline Kenya & 4.3 & & \\
\hline Kiribati & 4.3 & & \\
\hline Korea, North & 20.1 & & \\
\hline Korea, Republic Of & 14.4 & 7.7 & 16.4 \\
\hline Kuwait & 1.5 & & \\
\hline Kyrgyzstan & 25.6 & 30.0 & 13.3 \\
\hline Laos & 25.2 & 7.3 & 19.3 \\
\hline Latvia & 20.0 & 30.0 & 12.0 \\
\hline Lebanon & 4.7 & & \\
\hline Lesotho & 23.5 & & \\
\hline Liberia & 12.5 & & \\
\hline Libya Arab Jamahiriy & 7.7 & & \\
\hline Liechtenstein & 24.0 & & \\
\hline Lithuania & 22.7 & & \\
\hline Luxembourg & 23.3 & & \\
\hline
\end{tabular}




\begin{tabular}{|c|c|c|c|}
\hline Nation & Women MPs & $\begin{array}{r}\text { Younger MPs } \\
\text { (under 40) }\end{array}$ & Older MPs $(60+)$ \\
\hline Macedonia & 29.2 & & \\
\hline Madagascar & 7.9 & & \\
\hline Malawi & 13.0 & & \\
\hline Malaysia & 10.0 & & \\
\hline Maldives & 12.0 & & \\
\hline Mali & 10.2 & 8.2 & 13.6 \\
\hline Malta & 9.2 & & \\
\hline Mauritania & 22.1 & & \\
\hline Mauritius & 17.1 & & \\
\hline Mexico & 23.2 & & \\
\hline Micronesia, Fed Stat & 0.0 & 0.0 & 21.4 \\
\hline Moldova, Republic Of & 21.8 & 5.9 & 19.8 \\
\hline Monaco & 20.8 & & \\
\hline Mongolia & 6.6 & 10.7 & 4.0 \\
\hline Morocco & 10.5 & 9.2 & 18.8 \\
\hline Mozambique & 34.8 & 39.6 & 7.6 \\
\hline Namibia & 26.9 & 0.0 & 23.1 \\
\hline Nepal & 17.3 & & \\
\hline Netherlands & 39.3 & & \\
\hline New Zealand & 33.1 & & \\
\hline Nicaragua & 18.5 & & \\
\hline Niger & 12.4 & 15.0 & 12.4 \\
\hline Nigeria & 7.0 & & \\
\hline Norway & 36.1 & 24.2 & 4.8 \\
\hline Oman & 0.0 & 31.0 & 3.6 \\
\hline Pakistan & 21.1 & & \\
\hline Palau & 0.0 & & \\
\hline Panama Canal Zone & 16.7 & & \\
\hline Papua New Guinea & 0.9 & & \\
\hline Paraguay & 10.0 & & \\
\hline Peru & 29.2 & 18.3 & 8.3 \\
\hline Philippines & 20.5 & 8.7 & 43.5 \\
\hline Poland & 20.4 & 21.5 & 9.3 \\
\hline Portugal & 28.3 & & \\
\hline Qatar & 0.0 & & \\
\hline Romania & 9.4 & 13.3 & 11.6 \\
\hline Russian Federation & 14.0 & 18.6 & 11.2 \\
\hline Rwanda & 48.8 & & \\
\hline San Marino & 11.7 & & \\
\hline Sao Tome \& Principe & 1.8 & & \\
\hline Saudi Arabia & 0.0 & & \\
\hline Senegal & 22.0 & 13.3 & 20.0 \\
\hline Seychelles & 23.5 & 23.5 & 2.9 \\
\hline Sierra Leone & 13.2 & & \\
\hline Singapore & 24.5 & 16.7 & 7.1 \\
\hline Slovakia & 19.3 & 22.0 & 3.3 \\
\hline Slovenia & 12.2 & 10.0 & 13.3 \\
\hline Solomon Islands & 0.0 & & \\
\hline Somalia & 8.2 & & \\
\hline South Africa & 33.0 & & \\
\hline Spain & 36.6 & 16.6 & 11.2 \\
\hline Sri Lanka & 5.8 & & \\
\hline
\end{tabular}




\begin{tabular}{|c|c|c|c|}
\hline Nation & Women MPs & $\begin{array}{r}\text { Younger MPs } \\
\text { (under 40) }\end{array}$ & Older MPs $(60+)$ \\
\hline St. Kitts \& Nevis & 6.7 & & \\
\hline St. Lucia & 11.1 & & \\
\hline St. Vincent \& Grenadine & 18.2 & & \\
\hline Sudan & 18.1 & & \\
\hline Suriname & 25.5 & & \\
\hline Swaziland & 10.8 & & \\
\hline Sweden & 47.0 & 25.2 & 10.3 \\
\hline Switzerland & 28.5 & 11.5 & 16.5 \\
\hline Syrian Arab Republic & 12.0 & 44.8 & 4.4 \\
\hline Tajikistan & 17.5 & 15.9 & 0.0 \\
\hline Tanzania & 30.4 & & \\
\hline Thailand & 11.7 & 16.5 & 15.8 \\
\hline Togo & 11.1 & & \\
\hline Tonga & 3.3 & & \\
\hline Trinidad \& Tobago & 26.8 & 0.0 & 36.1 \\
\hline Tunisia & 22.8 & & \\
\hline Turkey & 9.1 & 9.8 & 15.1 \\
\hline Turkmenistan & 16.0 & & \\
\hline Tuvalu & 0.0 & & \\
\hline Uganda & 30.7 & & \\
\hline Ukraine & 8.2 & & \\
\hline United Arab Emirates & 22.5 & & \\
\hline United Kingdom & 19.5 & 12.7 & 14.1 \\
\hline United States & 16.8 & 6.4 & 28.7 \\
\hline Uruguay & 12.1 & & \\
\hline Uzbekistan & 17.5 & 23.3 & 1.7 \\
\hline Vanuatu & 3.8 & & \\
\hline Venezuela & 18.6 & & \\
\hline Viet Nam & 25.8 & & \\
\hline Western Samoa & 8.2 & 2.0 & 24.5 \\
\hline Yemen & 0.3 & & \\
\hline Yugoslavia & 20.4 & 30.4 & 6.0 \\
\hline Zambia & 15.2 & 13.9 & 11.4 \\
\hline Zimbabwe & 16.0 & & \\
\hline Total & 16.6 & 16.3 & 15.0 \\
\hline
\end{tabular}

Sources:

(i) Women in parliament 2008: Inter-Parliamentary Union. Women in National Parliaments. Geneva: Inter-Parliamentary Union. http://www.ipu.org/wmn-e/world.htm

(ii) Age distribution of MPs: annual volumes of the Chronicle of Parliamentary Elections for 2000-2008. Geneva: Inter-Parliamentary Union. 
Technical Appendix A2: Concepts and Measures

\begin{tabular}{ll}
\hline Variable & Definitions, coding and sources \\
$\begin{array}{l}\text { \% Women in } \\
\text { parliament }\end{array}$ & $\begin{array}{l}\text { Proportion of women in the lower house of the national parliament, latest } \\
\text { election 2005. Source: Inter-Parliamentary Union. }\end{array}$ \\
$\begin{array}{l}\text { \% Younger MPs } \\
\text { Proportion of representatives to the lower house of parliament under } 40 \text { years of } \\
\text { age. Source: Inter-Parliamentary Union. }\end{array}$
\end{tabular}

CIVIC

ENGAGEMENT

Voted

V234. "Did you vote in your country's recent elections to the national parliament?" Yes/no WVS 2005

Demonstrated V102: "Have you ever done any of these activities in the last five years? Attending lawful demonstrations."

Associational membership

Political interest

Importance of politics
V24-32: "Now I am going to read off a list of voluntary organizations. For each one, could you tell me whether you are an active member, an inactive member or not a member of that type of organization? V24. Church or religious organization V25. Sport or recreational organization V26. Art, music or educational organization V27. Labor Union V28. Political party V29. Environmental organization V30. Professional association V31. Humanitarian or charitable organization V32. Consumer organization." Summed and standardized to a 100-point scale. Source: World Values Surveys

V95. "How interested would you say you are in politics?" Scale from 'Not at all' (1) to 'Very interested' (4). Source: World Values Surveys

V7: 'For each of the following, indicate how important it is in your life. Politics' Scale from Scale from 'Not at all' (1) to 'Very important' (4) Source: World Values Surveys

\section{INDIVIDUAL- LEVEL CONTROLS}

Gender equality scale

Paid work status

Age
The combined 100-pt gender equality scale is based on the following 3 items: MENPOL Q118: "On the whole, men make better political leaders than women do." (Agree coded low); MENJOBS Q78: "When jobs are scarce, men should have more right to a job than women." (Agree coded low); BOYEDUC Q.119: "A university education is more important for a boy than a girl." (Agree coded low). Source: World Values Surveys

V220. "Are you employed now or not?" Coded fulltime, part-time or self-employed (1), other (0). Source: World Values Surveys

Age coded in continuous years derived from date of birth. Source: World Values Surveys. Age groups: Younger (18-29), middle (30-49), and older (50+). 


\begin{tabular}{|c|c|}
\hline Religiosity & V192 'How important is God in your life' 10-point scale \\
\hline Household Income & $\begin{array}{l}\text { V253 "On this card is a scale of incomes on which } 1 \text { indicates the "lowest income } \\
\text { decile" and } 10 \text { the "highest income decile" in your country. We would like to know } \\
\text { in what group your household is. Please, specify the appropriate number, counting } \\
\text { all wages, salaries, pensions and other incomes that come in." (Code one number). } \\
\text { Source: World Values Surveys }\end{array}$ \\
\hline Education scale & $\begin{array}{l}\text { V238. "What is the highest educational level that you have attained?" [NOTE: if } \\
\text { respondent indicates to be a student, code highest level s/he expects to complete]: } \\
\text { (1) No formal education; (2) Incomplete primary school; (3) Complete primary } \\
\text { school; (4) Incomplete secondary school: technical/vocational type; (5) Complete } \\
\text { secondary school: technical/vocational type; (6) Incomplete secondary: university- } \\
\text { preparatory type; (7) Complete secondary: university-preparatory type; (8) Some } \\
\text { university-level education, without degree; (9)University-level education, with } \\
\text { degree. Source: World Values Surveys }\end{array}$ \\
\hline \multicolumn{2}{|l|}{$\begin{array}{l}\text { NATIONAL LEVEL } \\
\text { CONTROLS }\end{array}$} \\
\hline $\begin{array}{l}\text { Historical } \\
\text { experience of } \\
\text { democratization }\end{array}$ & $\begin{array}{l}\text { Measured by the cumulative ratings for political rights and civil liberties provided } \\
\text { annually by Freedom House from } 1972 \text { to } 2005 \text {. Source: Freedom Around the } \\
\text { World. Freedom House. www.freedomhouse.org }\end{array}$ \\
\hline
\end{tabular}

Note: Full details of the World Values Survey codebooks and questionnaires can be found at www.worldvaluessurvey.com. 


\section{Acknowledgments:}

We would like to thank Martin Alonso at Harvard University for invaluable research compiling the data on the age profile of parliamentarians and Richard Niemi for providing data on the age profile of the U.S. Congress.

\section{References}

Abramson, Paul R. 1972. "Political Efficacy and Political Trust Among Black Schoolchildren: Two Explanations." Journal of Politics 34 (4): 1243-1269.

Alexander, Amy C. 2009. "Change in Women's Parliamentary Presence and Change in the Perception of Women's Ability to Rule: A 25 Nation Comparison." Unpublished manuscript.

Almond, Gabriel and Sidney Verba. 1963. The Civic Culture: Political Attitudes and Democracy in Five Nations. Princeton: Princeton University Press.

Atkeson, Lonna Rae and Nancy Carrillo. 2007. "More Is Better: The Influence of Collective Female Descriptive Representation on External Efficacy." Politics \& Gender 3 (1): 79-101.

Atkeson, Lonna Rae. 2003. "Not All Cues Are Created Equal: The Conditional Impact of Female Candidates on Political Engagement." Journal of Politics 65 (4): 1040-1061.

Banducci, Susan A., Todd Donovan, and Jeffrey A. Karp. 1999. "Proportional Representation and Attitudes About Politics: Results from New Zealand." Electoral Studies 18 (4): 533-555.

Banducci, Susan A., Todd Donovan, and Jeffrey A. Karp. 1999. "Proportional Representation and Attitudes About Politics: Results from New Zealand." Electoral Studies 18 (X): 533-555.

Banducci, Susan A., Todd Donovan, and Jeffrey A. Karp. 2004. "Minority Representation, Empowerment, and Participation." Journal of Politics 66 (2): 534-556.

Barnes, Samuel and Max Kaase. 1979. Political Action: Mass Participation in Five Western Democracies. Beverley Hills: Sage.

Barreto, Matt A., Gary M. Segura, and Nathan D. Woods. 2004. "The Mobilizing Effect of MajorityMinority Districts on Latino Turnout." American Political Science Review 98 (1): 65-75.

Best, Heinrich and Maurizio Cotta, eds. 2000. Parliamentary Representatives in Europe, 1848-2000. New York: Oxford University Press.

Blais, André. 2000. To Vote or Not to Vote? The Merits and Limits of Rational Choice Theory. Pittsburgh: University of Pittsburgh Press.

Bobo, Lawrence and Franklin D. Gilliam, Jr. 1990. "Race, Sociopolitical Participation, and Black Empowerment." American Political Science Review 84 (2): 377-393.

Borchert, Jens and Jürgen Zeiss, eds. The Political Class in Advanced Democracies. New York: Oxford University Press. 
Brace, Kimball, Lisa Handley, Richard G. Niemi, and Harold W. Stanley. 1995. "Minority Turnout and the Creation of Majority-Minority Districts." American Politics Quarterly 23 (2): 190-203.

Burness, Catriona. 2000. "Young Swedish Members of Parliament: Changing the World?" NORA 8 (2): $93-$ 106.

Burns, Nancy, Kay Lehman Schlozman, and Sidney Verba. 2001. The Private Roots of Public Action: Gender, Equality, and Political Participation. Cambridge: Harvard University Press.

Carey, John M. and Matthew S. Shugart. 1995. 'Incentives to Cultivate a Personal Vote: A Rank Ordering of Electoral Formulas.' Electoral Studies 14:417-40.

Cameron, Charles, David Epstein, and Sharyn O'Halloran. 1996. “Do Majority-Minority Districts Maximize Substantive Black Representation in Congress?" American Political Science Review 90 (4): 794812.

Campbell, David E. and Christina Wolbrecht. 2006. "See Jane Run: Women Politicians as Role Models for Adolescents." Journal of Politics 68 (2): 233-247.

Canon, David. 1999. Race, Redistricting and Representation. Chicago: University of Chicago Press.

Childs, Sarah. 2004. Women Representing Women: New Labour's Women MPs. New York: Routledge.

Dolan, Kathleen. 2006. "Symbolic Mobilization? The Impact of Candidate Sex in American Elections." American Politics Research 34 (6): 687-704.

Duverger, Maurice. 1955. The Political Role of Women. Paris: UNESCO.

Franklin, Mark N. 2004. Voter Turnout and the Dynamics of Electoral Competition in Established Democracies since 1945. New York: Cambridge University Press.

Franklin, Mark N., Patrick Lyons, and Michael Marsh. 2004. "Generation Basis of Turnout Decline in Established Democracies." Acta Politica 39 (2): 115-151.

Gans, Curtis. 2009. "African-Americans, Anger, fear and youth propel turnout to highest level since 1960." Report of the American University's Center for the Study of the American Electorate. American University News. http://www1.american.edu/ia/cdem/csae/pdfs/2008pdfoffinaledited.pdf

Gay, Claudine. 2001. "The Effect of Black Congressional Representation on Political Participation." American Political Science Review 95 (3): 589-602.

Gilliam, Franklin D., Jr., and Karen M. Kaufmann. 1998. "Is There An Empowerment Life Cycle? LongTerm Black Empowerment and Its Influence on Voter Participation." Urban Affairs Review 33 (6): 741-766.

Gosnell, Harold Foote. 1930. Why Europe Votes. Chicago: University of Chicago Press.

Hansen, Susan B. 1997. "Talking About Politics: Gender and Contextual Effects on Political Proselytizing." Journal of Politics 59 (1): 73-103. 
High-Pippert, Angela and John Comer. 1998. "Female Empowerment: The Influence of Women Representing Women." Women \& Politics 19 (4): 53-66.

Hilton, James L. and William von Hippel 1996. "Stereotypes." Annual Review of Psychology 47: 237-271.

Howell, Susan E. and Deborah Fagan. 1988. "Race and Trust in Government: Testing the Political Reality Model." Public Opinion Quarterly 52 (3): 343-350.

Hughes, Melanie M. 2008. Politics at the Intersection: A Cross-National Analysis of Minority Women's Legislative Representation. Ph.D. Diss., Ohio State University.

Inglehart, Margaret. 1979. 'Political Interest in West European Women.' West European Politics.

Inglehart, Ronald and Pippa Norris. 2003. Rising Tide. New York: Cambridge University Press.

Inter-Parliamentary Union. 1997. Men and Women in Politics. Geneva: IPU.

Inter-Parliamentary Union. 2000. Participation of Women in Public Life. Geneva: IPU.

Jennings, M. Kent and Laura Stoker. 2004. "Social Trust and Civic Engagement across Time and Generations." Acta Politica 39 (4): 342-379.

Jussim, Lee, and Christopher Fleming. 1996. "Self-Fulfilling Prophecies and the Maintenance of Social Stereotypes: The Role of Dyadic Interactions and Social Forces." In Stereotypes and Stereotyping, ed. C. Neil Macrae, Charles Stangor, and Miles Hewstone. New York: Guilford Press, 161-192.

Karp, Jeffrey A. and Susan A. Banducci. 2008. "When Politics is Not Just a Man's Game: Women's Representation and Political Engagement." Electoral Studies 27 (X): 105-115.

Koch, Jeffrey. 1997. "Candidate Gender and Women's Psychological Engagement in Politics." American Politics Quarterly 25 (1): 118-133.

Koning, Edward A. 2009. "Women for Women's Sake: Assessing Symbolic and Substantive Effects of Descriptive Representation in the Netherlands." Acta Politica 44 (2): 171-191.

Krook, Mona Lena. 2009. Quotas for Women in Politics: Gender and Candidate Selection Reform Worldwide. New York: Oxford University Press.

Krook, Mona Lena and Diana Z. O'Brien. Forthcoming. "The Politics of Group Representation: Quotas for Women and Minorities Worldwide." Comparative Politics.

Kunda, Ziva. 1999. Social Cognition: Making Sense of People. Cambridge: MIT Press.

Lapp, Miriam. 1999. "Incorporating Groups into Rational Choice Explanations of Turnout: An Empirical Test." Public Choice 98 (1-2): 171-185.

Lawless, Jennifer L. 2004. "Politics of Presence? Congresswomen and Symbolic Representation." Political Research Quarterly 57 (1): 81-99. 
Long, Samuel. 1978. "Personality and Political Alienation Among White and Black Youth: A Test of the Social Deprivation Model." Journal of Politics 40 (2): 433-57.

Lovenduski, Joni and Pippa Norris. 2003. "Westminster Women: The Politics of Presence." Political Studies 51(1): 84-102.

Lovenduski, Joni. Ed. 2005. State Feminism and Political Representation. Cambridge: Cambridge University Press.

Mansbridge, Jane. 1999. 'Should blacks represent blacks and women represent women? A contingent "yes".' Journal of Politics 61(3): 628-657.

Mansbridge, Jane. 2003. 'Rethinking representation.' American Political Science Review 97(4): 515-528.

McFarland, Daniel A. and Reuben J. Thomas. 2006. "Bowling Young: How Youth Voluntary Associations Influence Adult Political Participation." American Sociological Review 71 (3): 401-425.

Merriam, Charles Edward. 1924. Non-Voting: Causes and Methods of Control. Chicago: University of Chicago Press.

Michelson, Melissa. 2000. "Political Efficacy and Electoral Participation of Chicago Latinos." Social Science Quarterly 81 (1): 136-150.

Miller, Warren E. and J. Merrill Shanks. 1996. The New American Voter. Cambridge: Harvard University Press.

Morris, Aldon. 1992. "The Future of Black Politics: Substance Versus Process and Formality." In Ethnic Politics and Civil Liberties, ed. Lucius Barker. New Brunswick: Transaction, 168-174.

Norris, Pippa, ed. 1997. Passages to Power: Legislative Recruitment in Advanced Democracies. New York: Cambridge University Press.

Norris, Pippa, Joni Lovenduski, and Rosie Campbell. 2006. Closing the Activism Gap: Gender and Political Participation in Britain London: UK Electoral Commission.

Norris, Pippa. 2001. 'Women's Power at the Ballot Box.' For Voter Turnout from 1945 to 2000: A Global Report on Political Participation. $3^{\text {rd }}$ Edition. International IDEA: Stockholm.

Norris, Pippa. 2003. Democratic Phoenix. Cambridge: Cambridge University Press.

Norris, Pippa. 2006. Electoral Engineering. New York: Cambridge University Press.

O'Toole, Therese, David Marsh, and Su Jones. 2003. "Political Literacy Cuts Both Ways: The Politics of Non-participation among Young People." Political Quarterly 74 (3): 349-360.

O'Neill, Brenda. Ed. 2005. Gender and Social Capital Ed. New York: Routledge

Pantoja, Adrian D. and Gary M. Segura. 2003. "Does Ethnicity Matter? Descriptive Representation in Legislatures and Political Alienation Among Latinos." Social Science Quarterly 84 (2): 441-460.

Phillips, Anne. 1995. The Politics of Presence. New York: Oxford University Press. 
Pitkin, Hanna. 1967. The Concept of Representation. New York: Atherton Press;

Plutzer, Eric. 2002. "Becoming a Habitual Voter: Inertia, Resources, and Growth in Young Adulthood." American Political Science Review 96 (1): 41-56.

Putnam, Robert D. 2000. Bowling Alone. New York: Simon \& Schuster.

Reingold, Beth and Jessica Harrell. Forthcoming. “The Impact of Descriptive Representation on Women's Political Engagement: Does Party Matter?" Political Research Quarterly.

Rokkan, Stein. 1970. Citizens, Elections, Parties. Approaches to the Comparative Study of the Processes of Development. Oslo: Universitetsforlaget.

Rosenstone, Steven J. and John Mark Hansen.1993. Mobilization, Participation and Democracy in America. NY: Macmillan.

Rubenson, Daniel, André Blais, Patrick Fournier, Elisabeth Gidengil, and Neil Névitte. 2004. "Accounting for the Age Gap in Turnout." Acta Politica 39 (4): 407-421.

Russell, Andrew. 2005. "Political Parties as Vehicles of Political Engagement." Parliamentary Affairs 58 (3): 555-569.

Sapiro, Virginia and Pamela Conover. 1997. "The Variable Gender Basis of Electoral Politics: Gender and Context in the 1992 U.S. Election." British Journal of Political Science 27 (4): 497-523.

Schwindt-Bayer, Leslie A. and William Mishler. 2005. "An Integrated Model of Women's Representation." Journal of Politics 67 (2): 407-428.

Sears, David O. and Nicholas A. Valentino. 1997. "Politics Matters: Political Events as Catalysts for Preadult Socialization." American Political Science Review 91 (1): 45-65.

Solomos, John and Les Black. 1995. Race, Politics, and Social Change. New York: Routledge.

Stanley, Harold W. and Richard G. Niemi. 2010. Vital Statistics on American Politics 2009-2010, Washington, DC: CQ Press.

Swain, Carol M. 2006. Black Faces, Black Interests: The Representation of African Americans in Congress. New York: University Press of America.

Swers, Michele L. 2002. The Difference Women Make: The Policy Impact of Women in Congress. Chicago: University of Chicago Press.

Tate, Katherine. 1991. "Black Political Participation in the 1984 and 1988 Presidential Elections." American Political Science Review 85 (4): 1159-1176.

Tate, Katherine. 2003. Black Faces in the Mirror: African Americans and their Representatives in the U.S. Congress. Princeton: Princeton University Press. 
Tingsten, Herbert L. G. 1937. Political Behavior: Studies in Election Statistics. London: P.S. King.

Verba, Sidney, Nancy Burns and Kay L. Schlozman. 1997. 'Knowing and caring about politics: gender and political engagement.' Journal of Politics 59:1051-1072.

Verba, Sidney, Norman Nie, and Jae-on Kim. 1978. Participation and Political Equality: A Seven-Nation Comparison. New York: Cambridge University Press.

Wängnerud, Lena. 2009. "Women in Parliaments: Descriptive and Substantive Representation." Annual Review of Political Science 12: 51-69

Williams, Melissa S. 1998. Voice, Trust, and Memory: Marginalized Groups and the Failings of Liberal Representation. Princeton: Princeton University Press.

Wolbrecht, Christina and David E. Campbell. 2007. "Leading by Example: Female Members of Parliament as Political Role Models." American Journal of Political Science 51 (4): 921-939.

Young, Iris Marion. 2000. Inclusion and Democracy. New York: Oxford University Press.

${ }^{1}$ Full methodological details about the World Values Surveys, including the questionnaires, sampling procedures, fieldwork procedures, principle investigators, and organization can be found at: www.worldvaluessurvey.com

${ }^{2}$ These countries are ranked as equally 'free' according to the 2008 Freedom House assessments of political rights and civil liberties Freedom House. 2008. Freedom in the World. www.freedomhouse.org. 